\title{
RÉSULTATS D'ESSAIS DU GYGLOTRON DE GRENOBLE
}

\author{
P. DELPHIN et F. DUPONT, \\ C.S.F., Domaine de Corbeville, 9I-Orsay.
}

Résumé. - Les essais de réception en faisceau interne du Cyclotron de Grenoble ont eu lieu en octobre 1967 et ont été couronnés de succès ; le système d'extraction a ensuite été monté dans la machine et les essais de réception du cyclotron en faisceau extrait (protons) ont eu lieu en juillet 1968 . L'énergie du faisceau était de $50 \mathrm{MeV}$.

Le rendement d'extraction du cyclotron atteint couramment $70 \%$ entre sonde interne et fenêtre de sortie du faisceau; ce haut rendement étant dû à l'emploi de l'harmonique 1 de champ magnétique.

D'autres essais ont eu lieu à d'autres énergies $(40,30,19 \mathrm{MeV})$ et pour d'autres particules $(\alpha)$ montrant ainsi les possibilités de cette machine quant à la facilité d'extraction aux différentes énergies et pour différentes particules.

Abstract. - The internal beam acceptance of the Grenoble Cyclotron was successfully tested in october 1967. Then after assembly of the extraction system in the machine, acceptance on a proton extracted beam was analysed in july 1968 at an energy $50 \mathrm{MeV}$.

The extraction efficiency was often as high as $70 \%$ between the internal probe and the beam exit port. This high efficiency comes from using the first harmonic of the magnetic field.

Other tests were performed at various energies $(19,30,40 \mathrm{MeV})$ and for different particles $(\alpha)$. These show the possibilities of this machine for the easy extraction of beams of different particles at various energies. 